\title{
Towards new seed orchard designs in Germany - A review
}

\author{
Heike Liesebach ${ }^{1}$, Katharina Liepe ${ }^{1}$ and Cornelia Bäucker ${ }^{2}$ \\ ${ }^{1}$ Thuenen Institute of Forest Genetics, Sieker Landstrasse 2, 22927 Grosshansdorf, Germany \\ ${ }^{2}$ Thuenen Institute of Forest Genetics, Eberswalder Chaussee 3A, 15377 Waldsieversdorf, Germany \\ * Corresponding author: Heike Liesebach, E-mail: heike.liesebach@thuenen.de
}

\begin{abstract}
New first and 1.5 generation seed orchards are to be created in Germany based on recently assembled breeding populations of Acer pseudoplatanus, Larix sp., Picea abies, Pinus sylvestris, Pseudotsuga menziesii, and Quercus sp. To justify the high expenses in time and cost for orchard establishment and maintenance, planning should make use of consolidated knowledge and experience of both the national and international scientific community. Here, we briefly describe advances in genetic gains achieved through tree breeding, and resume population genetic aspects and design considerations to draw conclusions for clonal composition and spatial design of the new orchards.

We conclude that to avoid outbreeding depression separate orchards are required for each breeding zone. The zones are species-specific and defined by ecological and climatic aspects. A minimum of $60-80$ clones per orchard is recommended for native tree species with high proportions of natural regeneration in forest practice. This would allow future selective thinning based on estimated breeding values from progeny testing. It would also permit the transfer of seed orchard progenies into a naturally regenerating forest stands without the risk of a genetic bottleneck. Lower clone numbers are appropriate for non-native species and hybrids. It is important to strictly avoid inbreeding depression, achieved by using only one clone per progeny or population, from which the plus trees were selected. Further, the spatial layout should promote random mating by optimizing the neighbourhood of each clone. With all of these considerations taken into account, we expect superior quality traits and at least $10-15 \%$ more volume from the new seed orchards.
\end{abstract}

Keywords: Forest tree breeding, breeding population, plus trees, relatedness, inbreeding depression, outbreeding depression, heterosis, seed orchard design, clone number

\section{Motivation}

In forestry, natural regeneration is not always possible, or is not sufficient, so that planting with improved forest reproductive material is required. For that purpose, seed orchards and approved seed stands can produce seed for artificial regeneration and afforestation. In comparison to seed stands, seed orchards are time- and cost-intensive due to the necessary procedures for their establishment and maintenance. The higher expenses for seed orchards, therefore, have to be justified not only by a good ecological stability and health of the tree populations originating from seed orchards' seeds, but simultaneously by higher genetic gains, i.e., a superior value in timber quality and/or growth performance. Usually, this will be achieved by the selection of so-called plus trees, their vegetative propagation by graftings or cuttings, and the planting of these ramets to form synthetic populations, which allow mutual pollination.

The German Forest Tree Breeding Strategy was a result of in-depth discussions between experts from federal and state forest research institutes including international contributors. It was formulated and published in 2013 (Liesebach M et al. 2013). "The important goal of breeding is to provide reproductive material that is adaptable and powerful enough to meet expected environmental changes in performing all forest functions. ... Experiences show that ... significantly increased mass and value performance can be expected through breeding." 
(cited from the German Forest Tree Breeding Strategy, p. 1). Thus, it proposes the establishment of healthy, vital and adaptable forest tree populations as a precondition for the simultaneously desired good growth performance resulting in high yield. In addition to adaptation and adaptability, a good timber quality (e.g., stem form) should promote a cascade utilization of wood. In this regard, new seed orchards producing such high-quality seed are the anticipated outcome to transfer the results of forest tree breeding efforts into practice. Species-specific strategies for each of for the six focus tree species consider different levels of breeding intensity. For Pseudotsuga menziesii and Larix sp., more intense measures are planned, medium intensities are provided for Acer pseudoplatanus, Picea abies and Pinus sylvestris, and lowest intensity is intended for Quercus sp.. Since 2014, the nationally funded joint research projects "FitForClim" and "AdaptForClim" were conducted to realize first steps of the forest tree breeding strategy. They include the selection of plus trees, preferably in field trials, but also in forest stands, and the establishment of breeding populations. Three to four breeding zones for each of the six species were developed and delineated based on climatic, ecological and experimental data from field trials within Germany, e.g., for Pseudotsuga menziesii (Liepe and Liesebach M 2017, Liesebach M et al. 2020), for Quercus sp. (Meißner et al. 2020), and for Pinus sylvestris (Liesebach M et al. 2020). The plus tree selection was carried out using a multi-stage procedure that started with a comprehensive evaluation of field trial data at the progeny level, followed by an in-depth visual characterization to select individuals based on multiple traits (Liesebach M et al. 2020, Meißner et al. 2020). Selection criteria were an above-average stem form and growth performance, drought and late frost tolerance, and an above-average resistance against the most widespread typical fungal diseases (e. g., Lophodermium seditiosum and Diploidia sp. in Scots pine, Lachnellula willkommii in larch, Phaeocryptopus gaeumannii in the coastal variety of Douglas fir and Verticillium sp. in sycamore maple). In total, about 5001000 plus trees per specieswere selected, grafted and planted in breeding populations with at least 200 per breeding zone. The established breeding populations are replicated at two locations. Thus, the two projects prepared the preconditions for subsequent seed orchards assembled with grafted clones from each breeding zone.

These new seed orchards should be created in the light of consolidated knowledge and experience of both the national and international scientific community. Especially the aspect of relatedness of seed orchard clones should be considered as international studies have repeatedly shown disadvantageous effects of crossbreeding between relatives on the growth performance of seed orchards progenies. Besides superior quality traits, a range of 10-15\% more volume, at least for the conifer species, is the most likely we would expect as a result of new seed orchards assembled from the recently established breeding populations in Germany.

Here, after a short description of the baseline situation, we resume population genetic aspects and the current relevant literature with the objective to draw conclusions for the genetic composition and design of new seed orchards in Germany.

\section{Existing seed orchards at the national and international scale}

More than 300 seed orchards already exist in Germany, established over many decades, mainly for the species Pinus sylvestris (54), Larix sp. (49), Picea abies (44), Pseudotsuga menziesii (23), Alnus glutinosa (23), Prunus avium (20), and Tilia cordata (20). In total 255 seed orchards belong to the category "Qualified" and 50 to the category "Tested" (BLE 2019). They are very different in design and size, dependent on the locally available material and the desired growing region. All of these orchards have been established prior to the formulation of the longterm, continuous and trans-regional breeding strategy in 2013. Further, neither the breeding populations were consolidated in a common place until recently nor were breeding values of selected plus trees determined. In several cases, seed orchard progenies were tested in field trials according to the German forest legislation to evaluate them in comparison with officially recommended standards and progenies from approved seed stands. These tests showed that progenies of existing German seed orchards partially reveal superior quality traits. The average performance across seed orchard progenies, however, is more or less comparable with the average across progenies from approved seed stands and the well-growing standards. The latter being populations, approved for their performance by an expert advisory board and included in field trials for comparative purposes (gGA 2019). Top performing progenies are derived from seed orchards as well as from approved seed stands (e.g., Hüller et al. 1995, Stephan and Liesebach M 1996, Grotehusmann 1998, Rau 1998, Rau and Schulzke 2001, Schneck 2001, Grotehusmann 2014a, b). Up until now, it has not been possible to compare and evaluate different designs in the existing seed orchards (number and origin of clones, selection criteria) with the currently available progeny testing data in Germany (V Schneck, personal communication) because of highly variable preconditions.

At the international level, several countries have developed long-term and continuous breeding strategies for a number of economically important tree species. Breeding histories are reviewed, e.g., for the Scandinavian countries (Picea abies, Pinus sylvestris, Betula pendula by Jansson et al. 2017); France (Pinus pinaster by Merzeau et al. 2005); North America (e.g., Pinus taeda, Pinus elliottii by Li et al. 1999) or Australia and New Zealand (Pinus radiata by Burdon et al. 2008, Wu et al. 2008). Seed orchards are always the means to realize the so-called genetic gain as the result of breeding efforts. In this regard, genetic gain is quantified as the increase in average genetic value between two consecutive generations, being measured by the change in population means. Genetic gain varies from trait to trait and is greater if the selection is very intensive (only the very best individuals are selected) and the trait is under strong genetic control, i.e., has a high heritability.

Noteworthy timber volume gains of first-generation seed orchards have been achieved, for example, for Pinus elliottii in the US (+ $10 \%$, Vergara et al. 2004); Pinus radiata in New Zealand (+ $15 \%$, Carson et al. 1999); Pinus sylvestris in Finland (+ 15 
$\%$, Ahtikoski et al. 2012) or Picea abies in different Scandinavian countries (+ 9-15\%), but also for broadleaved species such as Alnus glutinosa (+ $10 \%)$ and Betula pendula (+ 10-15 \%) in Finland and Sweden (Haapanen et al. 2015).

Consecutive breeding cycles followed after the initial selection of plus trees, building on the established breeding populations and the estimation of breeding values by intensive progeny testing. It is generally expected that genetic gain improves with each generation of tree improvement compared to the unimproved material, while the magnitude of improvement decreases from one generation to the next. Even though growth traits have moderate to low heritabilities (h2 = $0.10-0.30$ ), they were originally and are still the main focus in many breeding programs (White et al. 2007). For the Swedish Scots pine breeding program, for example, Rosvall et al. (2001) summarize achieved gains of $10 \%$ volume increase per unit area for seed from first-generation orchards, 10-25\% (the latter for intense selections from a large number of field-tested plus trees) from the second generation and expect 20-25\% from third generation orchards established at the beginning of the Twenty-first Century. For the next generation, currently under establishment, they predict even up to $35 \%$ gain.

A strict economic viewpoint on seed orchards is common practice to increase yield and value of future forest stands to meet the rising demand of forest products. Tree breeding does, however, not only focus on growth traits. Quality traits such as wood density, stem straightness and branchiness are frequent breeding objectives, e.g., for European and hybrid larch (Kleinschmit 1988), Scots pine (Kohlstock and Schneck 1992), Norway spruce (Hansen and Roulund 1997) or Sitka spruce (Hannrup et al. 2004). In particular with climate change, adaptive traits (e.g., phenology, drought stress resistance, frost resistance) have become a new priority (Bastien et al. 2013, Chambel et al. 2013, Pâques 2013b, Ivetić et al. 2016). Increasing forest health by breeding for tolerance against pests and diseases has recently also been considered as a way to prepare for future challenges (Pâques 2013a, Haapanen et al. 2015). Taking climate change into account, German (Liesebach M et al. 2013) and Norwegian breeding programs (Edvardsen et al. 2010) have stated the objective to improve growth without a loss in wood quality and maintain genetic variation to sustain the adaptive potential of future forests.

From the retrospective point of view, MacLachlan et al. (2017) evaluated whether selective breeding (with the objective of an increased growth) did compromise the adaptive potential of Pinus contorta in Western Canada. Comparing seedlings from seed orchards and natural populations in a common garden they quantified the effect of selection on adaptive traits and whether these affect adaptive phenotype-climate associations. According to their conclusions, selection, breeding and progeny testing have produced taller seedlings that were not adaptively compromised relative to their natural seedling counterparts (MacLachlan et al. 2017). This gives selectively bred reproductive material a positive testimonial in light of climate change.

\section{Population genetic background}

\section{Comparison of natural vs. artificial regeneration}

Remarkable differences between natural and artificial regeneration exist in forest tree populations (reviewed, e. g., by Eriksson 1998, Hattemer and Ziehe 2018). Good professional practice can take care of the use of appropriate forest reproductive material and for the application of adequate timing and planting techniques. The genetic composition of the young forest generation, however, is always changed after artificial regeneration compared to natural processes, whereby some aspects must be considered.

In the natural regeneration of tree populations, a large amount of seed may be produced over long periods of time and several reproduction events cover annually fluctuating conditions. In contrast, artificial regeneration is usually based on a single reproduction event under singular conditions. In addition, the commercial harvest in approved seed stands prefers a seed collection from mothers with above average seed yields and, therefore, enhances naturally occurring differences in reproductive success.

To date, only a few studies exist on the amount of seed produced by natural forests. Sarvas (1962) analyzed 13 populations of Pinus sylvestris in Finland with seed traps for a maximum of 13 years and determined a mean value of 625,000 seeds per ha*year (total amount including filled and empty seed). Hofgaard (1993) studied a 400-year-old Picea abies natural stand in the northern boreal zone of Sweden over a nineyear period. The mean seed rain amounted to 767,000 per ha*year, but only very little seedling recruitment was observed due to large predation and unfavorable climatic conditions. Further, Saksa (2004) reported results of five unevenly-aged, spruce-dominated boreal forest stands in Finland. Depending on the fructification, he found a mean seed production ranging from $11 \mathrm{~kg} / \mathrm{ha} a^{*}$ year up to $28 \mathrm{~kg} / \mathrm{ha}$ in mast year, which corresponds to about 4.5 million seeds.

Commercial seed harvests in Germany collect up to 150 $\mathrm{kg} / \mathrm{ha}$ for Picea abies and $80 \mathrm{~kg} / \mathrm{ha}$ for Pinus sylvestris (BLE 2017) in mast years. That means 24 million and 13.6 million seeds per ha, respectively, to give an idea of the extent of reproduction excess (the larger seed harvests in Germany in comparison to Finland may be caused by more favorable growing conditions).

Under natural conditions, such an extremely high number of seed and seedlings experiences high random losses, but also a very strong viability selection against (partial) inbreeding. Thus, young generations will be drastically decimated by natural processes. In contrast, the nursery cultivation aims to achieve low random and selection losses of a given amount of seed. This can be realized due to more or less optimal growing conditions avoiding strong competition with irrigation, weed and pest control and the application of fertilizer. Nevertheless, there is a weak human- induced selection towards growth and vitality, because less vigorous seedlings are eliminated. In the next step of artificial regeneration, usually a few thousand seedlings per hectare are transferred into the forest, which is a relatively low number of seedlings compared to natural regeneration. 
In the case of artificial regeneration, the efforts of foresters are focused on the phenotypic selection for desired traits of adult trees at the population or at an individual level (strong selection). Then, the harvest of forest reproductive material is restricted to approved seed stands or seed orchards to use their seeds for the next forest generation. But, once this seed is available, further selection is largely avoided. At least in the nursery stage and in the early stand development, forest practice diminishes selection pressure by competition due to favorable plant spacing and even supports the desired species by manual treatments.

Therefore, particular attention is required for the production of forest seed to compensate or even overcompensate low rates of natural selection in the early phase of the offspring generation in the case of artificial regeneration.

\section{Effect of mating on growth and fitness of forest trees}

Most trees are outbreeding species that have developed different mechanisms against selfing: dioecism (e. g., Taxus, Populus, Fraxinus in parts), gametophytic self-incompatibility (in Rosaceae), the avoidance of contemporary flowering of male and female parts in hermaphrodite flowers (protandry, protogyny, e.g., in Juglans, Acer), the separation of female and male flowers in different parts of the crown (Picea), or frequent abortion of embryos after selfing resulting in empty seeds (in conifers). In contrast to annual plants, due to their longevity trees have many chances to produce offspring during their life.

Tree populations with continuous natural regeneration often show typical structures with correlated genetic and spatial distances (e.g., Gonzáles-Martínez et al. 2002 for Pinus pinaster, Cavers et al. 2005 for Symphonia globulifera, Eusemann and Liesebach H 2021 for Quercus petraea). These family structures result from restricted pollen flow and seed dispersal. More frequent pollination events between neighboring trees promote partial inbreeding, which is permanently present in natural populations. However, remarkable inbreeding depression leads to a strong selection against inbred offspring in early stages. As an example, in Scots pine, Danusevičius et al. (2016) found no more substantial changes in fixation index from the age of 20 years, indicating that the selection process against inbreeding has nearly finished.

Figure 1 shows a schematic and hypothetical curve summarizing the whole spectrum of possible constellations of mating within a species. On the $x$-axis, the possible degree of relatedness between mating parents ranges from selfing (possible in monoecious species) over mating among relatives of several degrees to mating of unrelated members within a population under natural conditions. Mating between individuals from separated and even long distant populations from the same species is also possible, which may lead to outbreeding depression in case of sexual reproduction or artificial crossing of local with transferred material from divergent environmental conditions. The $y$-axis quantifies the magnitude of growth and fitness-related traits.

\section{Inbreeding depression}

Without using the term "inbreeding depression," Charles Darwin wrote in his book "The Effects of Cross and Self-Fertilization in the Vegetable Kingdom" (Darwin 1877): "The first and most important of the conclusions which may be drawn from the observations given in this volume, is that cross-fertilization is generally beneficial, and self-fertilization injurious. This is shown by the difference in height, weight, constitutional vigor, and fertility of the offspring from crossed and self-fertilized flowers, and in the number of seeds produced by the parentplants." Nowadays, inbreeding depression is defined as reduced fitness (survival and fecundity) and/or reduced growth of progenies derived from selfing or mating of relatives compared to the parent(s). It is explained by an accumulation of deleterious, partially recessive alleles in mainly outcrossing species such as trees (Namkoong and Bishir 1987, Williams and Savolainen 1996).

According to a review of Pyhäjärvi et al. (2020) high inbreeding depression is very pronounced in Scots pine and many other conifers with large distribution areas (e.g., Picea abies, Pseudotsuga menziesii). They assessed the level of inbreeding depression to be lower in most angiosperms. In a study with Eucalyptus grandis, however, Hedrick et al. (2016) also observed a high number of deleterious alleles and a strong selection against homozygosity in a selfed progeny using SNP genotyping of about 10,000 heterozygous genes.

A large body of papers exists describing the negative effect of inbreeding in numerous tree species after controlled pollination experiments. Among them are some studies with specifically designed crossing schemes in order to quantify the effect of several levels of inbreeding. Mostly they include selfpollination (inbreeding coefficient $\mathrm{F}=0.5$ ), crosses between full-sibs or between parents and offspring $(F=0.25)$, crosses between half-sibs $(F=0.125)$ and outcrosses $(F=0)$. Such experiments require a breeding history longer than one generation to have access to parent trees with known pedigrees.

The following experimental examples prepared several levels of inbreeding. However, for comparative purposes the amount of depression is reported here only for an inbreeding coefficient of 0.25 . One of the first experiments with controlled crosses was started in 1978 with Pinus pinaster in France. At age 11 , the inbreeding depression amounted to $5 \%$ for height growth, $20 \%$ for volume and $37 \%$ for fecundity measured by number of cones (Durel et al. 1996). In the mid-1980s, Ford et al. (2014) conducted a similar experiment with Pinus taeda in the United States. At age 9, reductions for height growth of 6-13\% and for volume of 11-26\% depending on test sites were found. Stem straightness or fusiform rust disease incidence, however, were not affected by inbreeding. In Canada, Woods and Heaman (1989) carried out crossings for Pseudotsuga menziesii in 1987 and reported first results on the negative effect of inbreeding on the production of filled seeds. At the nursery stage, significant inbreeding effects were found for germination, seedling survival and growth (Woods et al. 2002). At age 26, the inbreeding depression of these progenies was finally estimated for height, diameter and volume growth accounting percentages of 12,22 and $43 \%$ respectively, while there was 


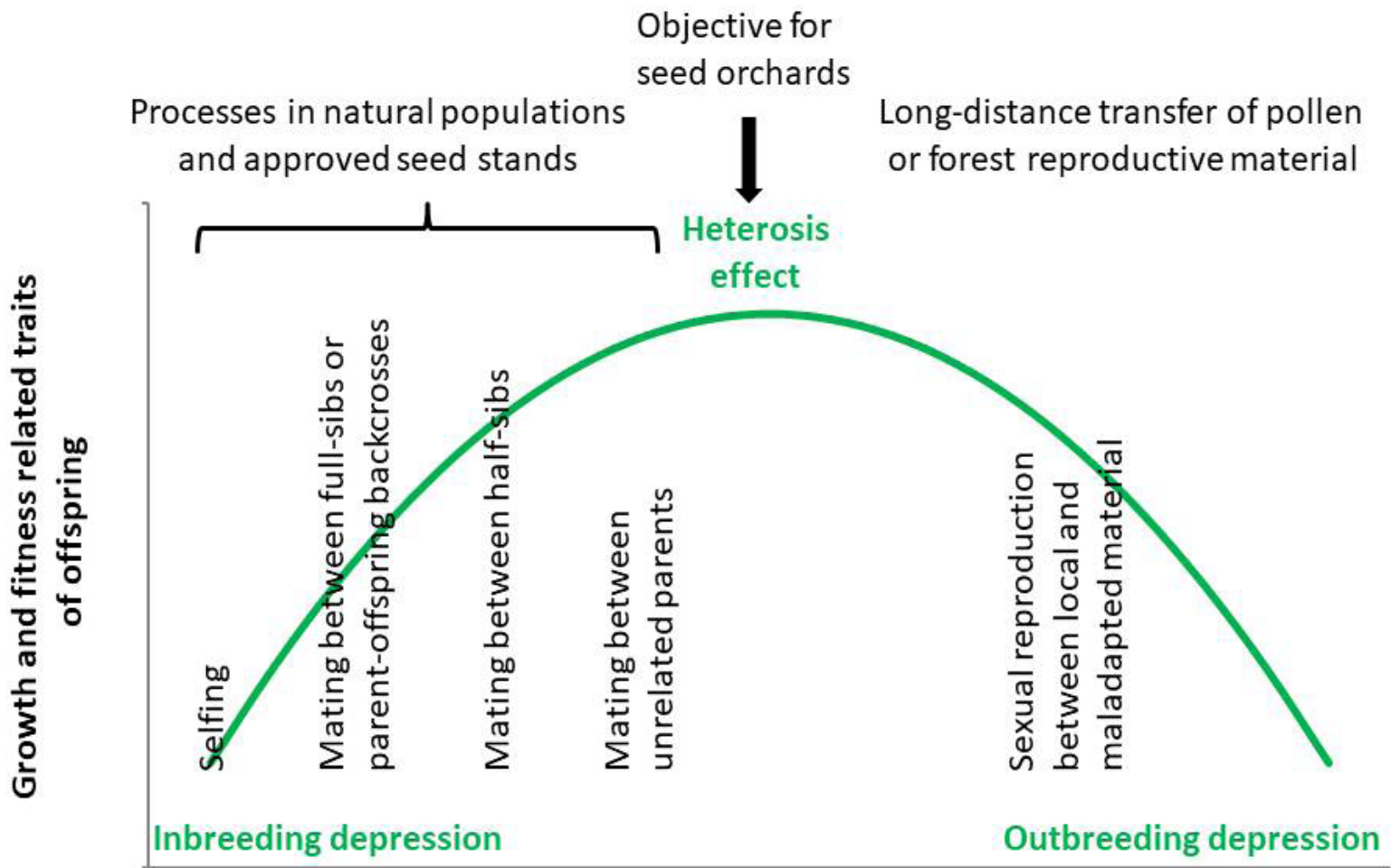

\section{Genetic distance among parents}

Figure 1

Scheme of the whole spectrum of possible constellations of within-species matings in relation to growth and fitness traits.

nearly no influence on wood density (Stoehr et al. 2015). Recently, in 2013 and 2014, a new series of crosses was conducted in Sweden with Pinus sylvestris creating 9 different inbreeding levels. As a preliminary result, $48 \%$ of the variance in the percentage of filled seeds was explained by inbreeding level (Mullin et al. 2019).

Inbreeding depression has also been reported for the offspring of seed orchards. As an example, Pupin et al. (2019) studied effects of inbreeding depression and found serious decreases of $18 \%$ for height, $26 \%$ for diameter and $20 \%$ for survival in Eucalyptus urophylla at an inbreeding level of 0.25. Doerksen et al. (2014) estimated the reduction of Picea glauca height growth to approximate $6 \%$ for every 0.1 increase in inbreeding coefficient.

Studies regarding natural populations often compare parameters of different ontogenetic stages. A few research papers report higher mean heterozygosities and outcrossing rates in adults compared to lower levels of heterozygosity and outcrossing rates in seeds or seedlings, e.g., in Pinus leucodermis (Morgante et al. 1993), in the neotropical tree Platypodium elegans (Hufford and Hamrick 2003) or in Picea jezoensis (but not in Abies sachalinensis) by Okada et al. (2015). The authors discussed their results in relation to viability selection against inbred offspring in natural populations.

\section{Outbreeding depression}

"An outbreeding depression occurs when fecundity and/or viability decline following an intraspecific hybridization. Coadaptation provides an explanation for outbreeding depression based upon the fitness interactions between genes." (cited from Templeton 1986). Outbreeding depression in the narrow sense is defined as a reduction in fitness of progenies below the average of the parents (Edmands 2007). However, there are different points of views, and sometimes outbreeding depression is considered as a significant decline in hybrid fitness relative to either parent. Two main mechanisms of outbreeding depression were referred to by Templeton (1986): The “... disruption of beneficial interactions between loci (intrinsic coadaptation or "coadapted gene complexes"), and disruption of beneficial interactions between genes and the environment (extrinsic or local adaptation)" (cited from Edmands and Timmerman 2003). The latter may be very typical for stand-forming tree species with large distribution areas growing under variable environmental conditions. Here, the adaptive and evolutionary potential of long-distance pollen flow has to be mentioned, since single individuals originating from such events may survive and reach the reproductive stage. In practice, it seems to be very difficult to develop experimental designs for tree species to separate the two different 
mechanisms resulting in outbreeding depression from each other. There are not only possible intrinsic genetic effects and the influence of the maladapted parent to the offspring performance at a given growing site, but also epigenetic effects that may modify experimental results. Although numerous experimental results of outbreeding depression are given for herbaceous plants (e.g., Edmands 2007 or Oakley et al. 2015), the phenomenon has rarely been studied in tree or shrub species.

Various crossings of Pinus sylvestris clones from divergent climatic regions were conducted in Germany in the 1970s and 1980s, however in an irregular non-reciprocal design. They resulted in reduced growth performance of progenies compared to combinations of locally adjacent parents (V Schneck unpublished). In a full diallel crossing scheme between six distant populations of Lotus scoparius, fruit set and seedling emergence were inversely related to the genetic distance between populations measured with isozyme markers (Montalvo and Ellstrand 2001). In controlled pollination experiments with neighboring and distant pollen donors, Stacy (2001) found an optimal distance for maximum fruit set of 1-2 km for Syzygium rubicundum and 2-10 km for Shorea cordifolia. Smaller and larger distances between the origin of parents led to a reduced reproductive fitness assigned to biparental inbreeding and outbreeding depression, respectively. A similar experiment was done by Forrest et al. (2011) with the shrub Grevillea mucronulata. They also found the best seed set and seedling performance for intermediate distance pollination compared to distant and open pollination treatments. Goto et al. (2011) carried out controlled reciprocal crossings with local (low-elevation) and non-local (high-elevation) parents of Abies sachalinensis and grew them at a low-elevation test site. They observed a reduced height and diameter growth of 25-year-old offspring families derived from one or two non-local parents and considered this as outbreeding depression. In this example, however, the distance relates to remarkable differences in ecological conditions due to elevation rather than to a pure geographic distance.

\section{Heterosis effect}

Heterosis (also called as hybrid vigor or outbreeding enhancement) is defined as superior growth or fitness of offspring compared to the mid-parent values. This term was mentioned the first time by Shull in 1914 in the context of maize breeding (Shull 1952), and, originally, it was restricted to enhanced growth after crosses between inbred lines. Meanwhile, the term heterosis is used in a much broader sense. Considering tree species, this term is sometimes also used for the positive effects due to hybridization among closely related species, e. g., for Larix (Pâques 2009), Liriodendron (Yao et al. 2016) or Populus (Rood et al. 2017, Zanewich et al. 2018). However, we regard heterosis as a within-species effect and look for the maximum of the curve in the scheme of Figure 1. Therefore, we refer to heterosis as an effect of so-called inter-provenance hybridization. Recessive or nearly recessive deleterious mutations that have become fixed within populations because of genetic drift may be responsible for heterosis after crosses between natural populations (Oakley et al. 2015).

There are some experimental results from controlled crossings, which investigate offspring families for their potential heterosis. An early attempt was made to exploit the heterosis effect for forest tree breeding in Sweden in the 1950s. Controlled pollinations were carried out with several selected clones of Picea abies derived from Sweden (used as females) and Germany (as pollen donors). Remarkable differences between families were found for stem volume at age 25 . A clear superiority of the inter-provenance families and indication for heterosis was observed at one out of three Swedish test sites (Eriksson and Ilstedt 1986). The authors explained the missing heterosis at the two other sites in relation to differences in growth rhythm and harsh conditions.

In France, a comprehensive diallel mating scheme was carried out for Pinus pinaster with 10 provenances from three geographic regions in 1978. The mean value of heterosis for height growth amounted to $8.4 \%$ at age 13 , however, no relationship between heterosis and stem crookedness or insect resistance was detected (Harfouche et al. 2000, Harfouche and Kremer 2000). Another full diallel crossing design with natural Eucalyptus globulosa trees in Tasmania was conducted in 1997-1998 to generate families from within-region and long-distance outcrossings (Lopez et al. 2003). At age 13, Costa e Silva et al. (2014) observed significant heterosis effects for family means of growth of long-distance crossings for one of the two test sites.

A second theoretical approach without known pedigrees is based on the reconstruction of relatedness by the application of genetic markers. Doerksen et al. (2014) used an array of nearly 6000 SNPs to determine genetic relationships in a field experiment including intra-provenance and inter-provenance crosses of Picea glauca. After removing partial inbreeding effects by detection of weak relatedness in the intra-provenance crosses, a heterosis effect of about $6 \%$ for height growth at age 15 had been found by comparing intra-provenance and inter-provenance progenies.

\section{Practical aspects for establishing seed orchards}

\section{Number of clones}

Many publications in forestry deal with the question of the adequate clone number for seed orchards, although the topic itself has never been fully discussed in the literature (Lindgren and Prescher 2005). This is surprising, given the fact that the number of parents in a seed orchard is one of the most fundamental questions for seed orchard genetics as mentioned by Funda and El-Kassaby (2012). A universal answer to this question, however, may not exist, because seeds from seed orchards are used for different purposes, under different local conditions and for native as well as for introduced tree species. On the one hand, seeds produced in seed orchards do only serve 
for commercial timber production, where improvement of genetic gain and consequently shorter rotation periods are the main foci. Such a strict economic viewpoint of seed orchards is common practice in countries with a long history in forest tree breeding. On the other hand, however, seed from seed orchards might also function as starting point for new forest tree populations, which should be able to regenerate naturally without a severe genetic bottleneck and with a low risk of a reduced adaptability to changing environmental conditions. Therefore, the number of seed orchard clones highly depends on the purpose of the resultant seed.

Regarding concrete recommendations for clone numbers for advanced breeding cycles, very different statements and details can be found in the literature. For example, Libby (1982) reported mixtures of 2-3 clones as the worst strategy and proposed numbers of 7-25 clones as robust strategy for seed orchards. Lindgren and El-Kassaby (1989) analyzed the question of optimal clone number from the viewpoint of maximizing genetic gain though genetic thinning. As initial scenario, the authors used a hypothetical seed orchard established with 50 progeny-tested clones. According to theoretical models of Bishir and Roberds (1997, 1999), moderate numbers of clones between 20 and 40 seem to be sufficient under general conditions and provide at least equivalent protection against catastrophic loss as does a large number of clones. Johnson and Lipow (2002), moreover, considered that $90 \%$ of isozyme variation found in natural populations can be achieved with seed orchards assembled of 20 or more clones under the assumption that clones are used in their native breeding zone. For British Columbia (Canada), it has been suggested that orchard seed lots for public land reforestation have been suggested to exceed an effective population size of 10 clones to realize a minimum level of diversity (Stoehr et al. 2004). Referring to conifers in Sweden, Lindgren and Prescher (2005) recommend 20 tested clones as a rule of thumb. This number of 20 is a commonly accepted minimum margin of unrelated clones being combined in an orchard that is supposed to serve for approximately 20 years, before being replaced by an advanced orchard (e.g. Danusevicius and Lindgren 2002, Lindgren and Prescher 2005).

In contrast to advanced generation seed orchards where the breeding values of clones are known, recommendations on the number of clones for first-generation seed orchards have seldom been published. For early seed orchards of Pinus sylvestris in northern Sweden, Andersson et al. (2003) compared growth performance and survival of progenies from 11 orchards each composed of 20-59 clones at the time of progeny testing. They mentioned that some of these orchards were later extended leading to clone numbers ranging from 20 to 112 in the year 2003. Recently, a number greater than hundred has also been reported by Yang et al. (2020) designing a firstgeneration seed orchard of $P$. sylvestris var. mongolica with 108 clones in total. Sønstebø et al. (2018) mentioned 60-200 untested and unrelated plus trees in Norwegian Norway spruce seed orchards belonging to the first generation. Such high numbers of clones definitely create more options and greater flexibility for later changes and decisions. This may include the transfer into advanced generation seed orchards after the testing of clones, but also managing seed orchard progenies as permanent forest with natural regeneration.

Moreover, a large number of clones ensures genetic diversity, which is essential for the long-term survival of forests under a changing environment (Ivetić et al. 2016). In this respect, the general tendency that a lower number of clones in a seed orchard causes a reduced genetic diversity of the resultant seed crops has been emphasized in some studies. For example, Sønstebø et al. (2018) investigated the genetic diversity of seed from two Norway spruce seed orchards with different number of parents ( 25 and 60 ) and compared them with seed from approved seed stands and natural forests. They found a decrease in allelic richness (-6 \%) and remarkably lower effective population sizes $(-71 \%)$ for the seed originating from the seed orchards compared to the other studied samples.

Another important aspect for the quality and genetic diversity of seed from seed orchards of wind-pollinated tree species is pollen flow from nearby forests, as shown by a large body of literature (e.g., Adams and Burczyk 2000, Fries et al. 2008, Fernandes et al. 2008, Torimaru et al. 2009, Korecký and El-Kassaby 2016, Sønstebø et al. 2018). These marker-based studies estimated a pollen contamination of up to about $50 \%$ in case of common tree species within their natural range.

Besides the detrimental effect of losses in genetic gain through pollen contamination (e. g., Di-Giovanni and Kevan 1991), pollen flow from outside has also been regarded to be of great importance for the genetic diversity of seed produced by seed orchards with a lower number of clones because gene flow always increases effective population size (e.g., Sønstebø et al. 2018). According to Ingvarsson and Dahlberg (2019), a higher genetic variation determines fitness in natural populations and the persistence under changing environmental conditions. The current tendency is that the speed of climatic shifts will surpass forest rotations of 40 to 60 years. Therefore, we suggest including the aspect of high genetic diversity into future orchards. To achieve this, we propose to establish the new seed orchards with clone numbers between 60 and 80 for species native to Germany. These numbers might be a compromise between feasibility from a practical point of view and sufficient genetic diversity as estimated by Wojacki et al. (2019). For the non-native species Douglas fir, the number of 40 clones per seed orchard may be sufficient. Compared to the native tree species, this reduced number of clones must be seen in the context of planned seed imports from the native range to supplement the genetic diversity, as outlined in the German breeding strategy. Recently, a marker-based study in older Douglas fir seed orchards and their offspring was carried out in Germany. The results show a better transfer of genetic diversity to the offspring compared with Douglas fir seed stands having comparable numbers of genotypes in the adult population (Pakull et al. unpublished).

Contrary to this suggestion, seed orchards to produce species hybrids should be assembled differently since they represent a special case. Here, the objective is to combine selected clones of European and Japanese larch in order to 
breed seed with a high percentage of hybrids, which are superior to both parental species (hybrid vigor or heterosis effect in its broadest sense). For this purpose, seed are generally only harvested from one parental species, while the other is only the pollen donor and represented by a larger number of clones. Crucial for successful hybridization is a synchronous flowering time of the parental genotypes. Extreme, but very successful in terms of hybrid percentage and performance of the offspring, is the design proposed by Langner combining one single clone of Larix decidua with more than 200 clones of Larix kaempferi as pollen donors (Langner and Schneck 1998). In this case, inbred seed due to selfing of the mother clone are either empty or highly mortal in the seed bed.

\section{Relatedness}

The avoidance of genetic relatedness or co-ancestry among individuals is an important aspect in forest tree breeding and seed production in clonal seed orchards. Since the 1960s, the topic is under discussion mainly in North America (e. g., Pinus taeda, Pinus elliottii), in Scandinavian countries (Picea abies, Pinus sylvestris) and New Zealand (Pinus radiata). Opposite effects would arise between an enrichment of desired growthenhancing alleles and inbreeding depression in continued breeding cycles. Theoretical backgrounds were considered, e.g., by Namkoong (1966) and Burrows (1970).

Since the 1970s, several efforts were made always with the objective to avoid co-ancestry among individuals in the production seed orchards (Zobel et al. 1972, Talbert 1979, McKeand and Beineke 1980). In this context, ideas have been developed to keep breeding populations unrelated, like nested polycross designs, disconnected diallels, breeding groups, or sublining. "Selections within a breeding group are unrelated to selections in any other breeding group in order to allow complete avoidance of inbreeding in seed from wind-pollinated clonal seed orchards established with 1 clone from each group" as stated by White et al. (1993) for the example of Pinus elliottii.

With the increasing establishment of advanced generation seed orchards, tree breeders aimed to find the optimal balance between maximization of genetic gain and maintenance of genetic diversity through control of relatedness. In the 1990s, some models from animal breeding (Wray and Goddard 1994) were adapted to forestry, and Lindgren and Mullin (1997) were among the first, who implemented an advanced generation tree breeding strategy considering a compromise between genetic gain and an acceptable level of relatedness. They proposed to take a weighting factor into account considering breeding values and penalties for co-ancestry of the considered clones. An example is given by Olsson et al. (2001), who reported the successful application in Pinus taeda breeding. They compensate a certain amount of relatedness with a larger number of clones in order to obtain an additional genetic gain. Danusevičius and Lindgren (2002), further, investigated genetic gain by using results of experiments on Norway spruce and calculated various parameters like diversity loss per breeding cycle or costs per plant in $\$$ for different scenarios of three breeding strategies (phenotype, clone, progeny strategy). Danusevičius and Lindgren (2008), moreover, compared several selection models for candidate clones from unrelated half-sib families with known breeding values and with a predicted level of inbreeding depression. In this comprehensive simulation study, they found a maximized genetic gain for a given gene diversity in case of an optimal proportion deployment strategy, which is more efficient at higher levels of relatedness in the candidate population. Besides, Lindgren et al. (2009), focusing on different selection strategies such as truncation selection and linear deployment, reported a clear superiority of the latter approach concerning genetic gain. Interestingly, the linear deployment strategy, which uses clones in different proportions according to their breeding value (Lindgren and Matheson 1986), outperformed the classical truncation approach under the conditions of both no relatives and allowing related clones. Linear deployment had also been emphasized by Danusevičius and Lindgren (2008) to be an applicable method for seed orchard designs in advanced breeding cycles. Further, several computer-based methods simulating selection over generations were developed in order to support an optimal clone selection in tree breeding. The most recent is the program "OPSEL" introduced by Mullin (2014, 2017). The focus of "OPSEL" is to maximize the genetic value through the selection of certain cohorts, while a constraint on acceptable genetic diversity has to be maintained. The program can manage balanced and unbalanced numbers of ramets per clone (Yamashita et al. 2018).

The search for optimal strategies and compromises considering genetic gain as well as genetic diversity is still under discussion. In contrast to citations above, Silva et al. (2018) recommend the restriction to one tree per family in Eucalyptus urophylla breeding, accepting a slight decrease (0.9-1.5 \%) in genetic gain to insure genetic variation for next generations.

Regarding the new seed orchards in Germany, the relatedness of clones selected from a progeny of a field test or within a population is unknown, but a potential relatedness of clones may exist. The existence of distinct family structures, especially half-siblings, in a standard provenance field trial was shown in a case study with European beech (Liesebach H et al. 2015). Since the vast majority of plus trees was selected in provenance field trials, we strongly recommend avoiding arrangements where several clones from one progeny or one population are planted together in an orchard. Thus, the new seed orchards should be assembled using only one clone per progeny or population, if the desired number of clones can be achieved in this way. In cases with low available numbers of progenies or populations, from which the plus trees were selected, several seed orchards with non-overlapping clonal compositions could be established to avoid crossbreeding of potentially related clones. To establish new forest stands, the resulting seed lots should then be combined to achieve a larger genetic variation. Furthermore, we suggest composing the orchards with clones in equal proportions because information on breeding values, which might offer options for linear deployment, does not exist yet. 


\section{Spatial design of seed orchards}

Seed orchard designs aim to promote many different crosspollinations by using a repeated and randomized layout of clones. Since the beginning of forest tree breeding, a wide variety of spatial designs of seed orchards have been developed, and the availability of computational tools (Tab. 1), as well as the development of molecular methods opened up new perspectives regarding the layouts. In practice, therefore, clones had been planted according to numerous different seed orchard layouts (SOL), which makes direct comparisons between seed orchards very complex. Moreover, layouts are seldom published (but see D'Amico et al. 2019) and only some studies report specific details about the arrangement and spacing of clones and their ramets, respectively (e.g., Torimaru et al. 2013). Further, there is still an ongoing discussion on the topic of the best layout for seed orchards; even though, an all-in-one solution may not exist. As Lstibůrek and El-Kassaby (2008) concretely mentioned "neither design will be optimal in every situation due to year-to-year variability in reproductive output". Also, circumstances under which seed orchards are established vary from case to case, so that the decision for a layout has to be based on the consideration of different aspects: biology of the tree species, for example monoecious/dioecious or wind-/ insect-pollinated (e.g., Van Buijtenen 1975), environmental conditions like size and shape of the orchard, wind direction by which the pollen cloud might be transferred, as well as number of selected clones, number of ramets per clone (balanced/ unbalanced), and the presence of related clones as sib-mating or parent-offspring mating in advanced generations.

Historically, tree breeders focused primarily on the randomization of clones during the initial phase of a seed orchard's establishment. Giertych (1975) gives an excellent overview about these early strategies by comparing 14 different approaches, which include, for example, the Randomized Complete Block design as realized in a Prosopis alba seed orchard in Argentina (D'Amico et al. 2019) or the Systematic design as used for the arrangement of ramets in a seed orchard of $P$. menziesii in western Oregon (Slavov et al. 2005). Systematic and simple designs may be also useful if the clones need to be identified for use in controlled crossings. Further, some of these early designs already explicitly considered both the pollen flow by wind and the aspect of panmixia in the seed orchard like the Directional Cyclic Balanced Incomplete-Block (Freeman 1967) or the Permutated Neighborhood Design (PND) by La Bastide (1967). In particular, the computerized approach of Permutated Neighborhood has to be emphasized here because it provided the basis for later developments of software codes. One of those later programs was introduced by Bell and Fletcher (1978) with the name Computer Organized Orchard Layouts (COOL) and used for the establishment of some prominent seed orchards existing in British Columbia (Canada). A well-studied example is the second-generation seed orchard of P. menziesii established in 1990 (Lai et al. 2010, Kess and El-Kassaby 2015, Korecký and El-Kassaby 2016, Song et al. 2018), another one is a first-generation orchard of Larix occidentalis from 1989 (Funda et al. 2008). In the following years, the COOL approach was further developed under the name of Permutated Neighborhood Seed Orchard Design by Chakravarty and Bagchi $(1993,1994)$. But, neither the original COOL software code nor its enhanced version were designed to avoid inbreeding or to incorporate relatedness among clones. These features, however, were already considered by Vanclay (1991), who developed the computer program Seed Orchard Designer (SOD). This software was explicitly intended for second generation seed orchards with a high proportion of related clones.

Due to the accumulating evidence that any kind of relatedness of clones compromises the long-term genetic gain of seed orchards (see chapter "Inbreeding depression"), the minimization of inbreeding effects became more and more the focus in forest tree breeding during the first decade of the new century. In 2010, the Minimum-inbreeding seed orchard design (MI), which calculates spatial distributions among individual trees as a function of the extent of their genetic relatedness was published by Lstibůrek and El-Kassaby (2010). Still today, the Ml-design is superior to other approaches for allocating ramets of related clones or ramets of the same clone with the greatest possible distance along the orchard's grid (Chaloupková et al. 2016). The software can be used for various seed orchard scenarios such as balanced/unbalanced numbers of ramets per clone, including situations where clones are strongly underrepresented; different deployment strategies like linear or proportional deployment, or a mixture of genetic relatedness between clones, for example presence of both half-sib clones and parent-offspring mating. The Ml-code, furthermore, is also suitable for large and complex advanced generations through its subsequent improvement to an extended global algorithm (MI-EGA) by Lstibůrek et al. (2015). Parallel to the development of the Ml-design, another software program, the Randomized, Replicated, Staggered Clonal-Row design ( $\mathrm{R}^{2} \mathrm{SCR}$ ), has also been introduced (Lstibůrek and El-Kassaby 2010, El-Kassaby et al. 2014). The R²SCR-design overcomes difficulties arising from severe correlated mating in the classical clonal-row design (El-Kassaby 2003, El-Kassaby et al. 2007) because the staggering and randomization of rows promotes outcrossing among clones. The big advantage of an arrangement of clones in rows is the facilitation of individual clone management during harvest, pollination and pest control. The software, moreover, is flexible and can handle genetically related clones via exclusion zones, empty positions along the orchards' grid, as well as non-plantable spots. However, the $\mathrm{R}^{2} \mathrm{SCR}$-design is primarily intended for seed orchards of conifers with severe inbreeding depression after selfing and polyembryony (El-Kassaby et al. 2014). Recently, another algorithm with the name Improved Adaptive Parallel Genetic Algorithm (IAPGA) was demonstrated by Yang et al. (2020) using microsatellite data of $P$. sylvestris var. mongolica. The IAPGA approach, which was originally developed by Wang et al. (2018), uses the genetic distance among clones to minimize the effect of inbreeding depression through improved spatial clonal deployment. Hence, the aim of IAPGA is maximum spatial distance between clones of closer genetic relationship to maintain genetic diversity in the next generation. 
Tab. 1

Overview of the most relevant software programs for the design of seed orchard layouts (SOL).

\begin{tabular}{|c|c|c|}
\hline Software & Reference and code availability & Software features \\
\hline $\begin{array}{l}\mathrm{COOL} \\
\text { Computer } \\
\text { Organized } \\
\text { Orchard Layout }\end{array}$ & $\begin{array}{l}\text { Bell and Fletcher (1978), } \\
\text { code on request from authors (in Fortran) }\end{array}$ & $\begin{array}{l}\text { The code is based on the Permutated Neighborhood Design (PND) of La Bastide } \\
\text { (1967). It is applicable for both regular and irregular types of SOL. Planting places } \\
\text { are rectangularly arranged and different degrees of separation between the clones } \\
\text { (design types) are possible. Up to } 100 \text { clones with different numbers of ramets can } \\
\text { be handled, but no consideration of clone relatedness. }\end{array}$ \\
\hline $\begin{array}{l}\text { Permutated } \\
\text { Neighbourhood } \\
\text { Seed Orchard } \\
\text { Design }\end{array}$ & $\begin{array}{l}\text { Chakravarty and Bagchi }(1993,1994) \text {, } \\
\text { code on request from authors }\end{array}$ & $\begin{array}{l}\text { The code is based on the PND (La Bastide 1967). It can be used for rectangular, } \\
\text { triangular or hexagonal plots. Up to } 1000 \text { clones with an equal number of ramets } \\
\text { can be handled. Ramets per clone are separated by an inner and outer isolation } \\
\text { ring. No consideration of clone relatedness. }\end{array}$ \\
\hline $\begin{array}{l}\text { SOD } \\
\text { Seed Orchard } \\
\text { Designer }\end{array}$ & $\begin{array}{l}\text { Vanclay (1991), } \\
\text { code on request from author (in Fortran 77) }\end{array}$ & $\begin{array}{l}\text { The code was designed for } 2 \text { nd generation SOL. It creates PNDs and can handle } \\
\text { high proportion of related clones, which are separated by maximum distance. The } \\
\text { program is flexible and information on flowering or biology (dioecy) can also be } \\
\text { incorporated. }\end{array}$ \\
\hline $\begin{array}{l}\text { MI } \\
\text { Minimum- } \\
\text { inbreeding seed } \\
\text { orchard design }\end{array}$ & $\begin{array}{l}\text { Lstibůrek and El-Kassaby (2010), } \\
\text { calculations possible in cooperation with Lstibůrek }\end{array}$ & $\begin{array}{l}\text { The algorithm is suitable for } \mathrm{SOL} \text { of first and advanced generations with a rectan- } \\
\text { gular arrangement of planting places. Various degrees of relatedness and different } \\
\text { numbers of ramets per clone are possible. Inbreeding and mating among relatives } \\
\text { are avoided by maximizing the distance between ramets of a clone and related } \\
\text { clones, respectively. }\end{array}$ \\
\hline $\begin{array}{l}\text { R}^{2} \text { SCR } \\
\text { Randomized, } \\
\text { Replicated, } \\
\text { Staggered Clonal- } \\
\text { Row Design }\end{array}$ & $\begin{array}{l}\text { El-Kassaby et al. (2014), } \\
\text { calculations possible in cooperation with El-Kassaby }\end{array}$ & $\begin{array}{l}\text { The algorithm is suitable for all generation types of seed orchards with a rectangu- } \\
\text { lar arrangement of planting places. The design facilitates a selective seed harvest } \\
\text { by clone because several ramets of one clone are systematically planted in a row (= } \\
\text { clonal-row). The impact of selfing and correlated matings is minimized by stagge- } \\
\text { ring and maximal separation of clonal-rows of the same clone and related clones, } \\
\text { respectively. }\end{array}$ \\
\hline $\begin{array}{l}\text { MI-EGA } \\
\text { Minimum- } \\
\text { inbreeding seed } \\
\text { orchard design- } \\
\text { extended global } \\
\text { algorithm }\end{array}$ & $\begin{array}{l}\text { Lstibůrek et al. (2015), } \\
\text { code included in supplementary material (in R) }\end{array}$ & $\begin{array}{l}\text { The code is based on the Ml-approach and has been explicitly developed for large } \\
\text { and complex advanced generation seed orchards, seed orchards designs, e.g. SOL } \\
\text { with } 900 \text { planting places. The procedure includes: } 1 \text { ) subdividing the orchard's } \\
\text { grid into independent blocks and using the original Ml-algorithm for each block } \\
\text { independently, 2) rotation and merging of blocks using a random operator. Various } \\
\text { numbers of ramets per clone and different degrees of relatedness are possible. }\end{array}$ \\
\hline $\begin{array}{l}\text { ONA } \\
\text { Optimum } \\
\text { Neighbourhood } \\
\text { Algorithm }\end{array}$ & $\begin{array}{l}\text { Chaloupková et al. (2016), } \\
\text { free download at: } \\
\text { https://katedry.czu.cz/en/kgfld/software (in R) }\end{array}$ & $\begin{array}{l}\text { The algorithm is suitable for all generation types of seed orchards with a rectangu- } \\
\text { lar arrangement of planting places. The design enhances panmixia (random mating) } \\
\text { by optimization of the clone's' neighborhood. This is achieved through a reduced } \\
\text { variance in the number of direct neighbors of a clone. It is the most appropriate } \\
\text { design, when a clone has to be surrounded by as many different neighbors as } \\
\text { possible. }\end{array}$ \\
\hline $\begin{array}{l}\text { IAPGA } \\
\text { Improved } \\
\text { Adaptive Parallel } \\
\text { Genetic } \\
\text { Algorithm }\end{array}$ & $\begin{array}{l}\text { Wang et al. (2018), Yang et al. (2020), } \\
\text { formula and software tools included in publications }\end{array}$ & $\begin{array}{l}\text { The approach is suitable for all generation types of seed orchards. The method is } \\
\text { genetic distance-dependent and uses molecular data (SSR) to achieve an optimal } \\
\text { clone deployment in a seed orchard by maximizing spatial distance between clones } \\
\text { of closer genetic relationship. Applicable for rectangular layouts, where each clone } \\
\text { is surrounded by eight neighbors. }\end{array}$ \\
\hline
\end{tabular}

Further, an alternative approach to ensure high genetic diversity of seed orchards' progenies has been suggested by Chaloupková et al. (2016) under the name Optimum Neighborhood Algorithm (ONA). Compared to previous software tools, which concentrated on maximum distance of ramets of the same or related clones, the focus of ONA is the promotion of panmixia. This is achieved by optimization of the neighborhood of each clone and their ramets, respectively. This means that each ramet is surrounded by a more or less equal number of differing clones; hence, the variance of direct neighbor counts is minimized and achieves zero when all surrounding counts are equal. The pollen cloud, therefore, can be expected to reach the greatest level of optimal mixing, which promotes panmixia. In this regard, the ONA is significantly superior to other software tools, such as MI or R²SR (Chaloupková et al. 2016). The algorithm, furthermore, can handle variable clonal sizes, irregular plots, relatedness, assortative mating, and it is applicable for the upgrading of existing seed orchards, when new parents are introduced to replace failed clones or those of lower quality (Chaloupková et al. 2019). Moreover, the code for ONA is freely available (Tab. 1), and an additional ONA version has been developed for MATLAB (M. Lstibůrek, personal communication). 


\section{Conclusions for new seed orchards in Germany}

Currently, new first-generation clonal seed orchards are planned in Germany. For tree species, where plus trees of the recently installed breeding populations were selected predominantly in field trials, the planned seed orchards could be considered as the 1.5 generation. This is reasonable, since plus trees were selected for their superiority under comparable growing conditions, although their breeding values are so far unknown. The following criteria should be considered for the establishment of new seed orchards:

1. All seed orchards should consist of clone collections suitable for one of the three or four species specific breeding zones to avoid outbreeding depression. Germany is located partially in the Atlantic climate and partially in the transition to the continental climate; as a result, species-specific reactions to different environmental conditions are not uniform. Therefore, these zones were delineated considering climatic and ecological data and, if possible, verified by retrospective analysis of existing transplant experiments.

2. Generally, a number of 40 clones per seed orchard is recommended in the current German regularities for forest reproductive material. However, the number of clones to be used in the new seed orchards should consider species-specific aspects. We recommend a number of $\mathbf{6 0 - 8 0}$ clones for the native tree species Pinus sylvestris, Picea abies, Larix decidua, Acer pseudoplatanus and Quercus sp.. Such numbers of clones are feasible and will keep options open, e.g., for future selective thinning or to transfer seed orchard progenies into a naturally regenerating forest stand without the risk of a genetic bottleneck. At present, we cannot expect a better growth performance of seed orchard progenies by reducing clone numbers with a stronger selection because selection criteria (i.e., breeding values) are not yet available. Further, it is currently not possible to create a conclusive performance ranking among the selected plus trees as they originated from stands and trials, which include various trial series with different source collections and sites of divergent growing conditions. For the non-native species Douglas fir, the number of 40 clones per seed orchard may be sufficient. In case of hybrid larch, the objective is to produce seed with a high percentage of high-performance hybrids between selected European and Japanese clones. This should be realized by harvesting seeds from one individual, but replicated, clone of the maternal species, while the other species functions as the pollen donor and may be represented by a larger number of clones. A natural regeneration of the planted hybrid progeny is out of question.

3. With regard to the assembly of each single orchard, a very important point is to use only one clone per progeny or per population existing in the clonal archives. This procedure will ensure the promotion of the heterosis effect in the sense of inter-provenance hybridizations and a strict avoidance of potential inbreeding depression in the seed orchard progenies. In cases of multiple selection of plus trees from one progeny in a field test or from one population, a potential relatedness of selected clones has to be assumed. For most species considered here, there is no need for a combination of clones, which might be potential relatives, regarding the high number of selected plus trees for the respective breeding zones and the number of planned seed orchards. Alternatively, admixtures of seed lots from smaller seed orchards with non-overlapping clonal composition could be produced.

4. The clones should be used in equal proportions of ramets because breeding values giving information about the best clones to incorporate other approaches, e.g., linear deployment, are not available at the moment. Hence, the major focus of the new round of seed orchards will be random mating (i.e., panmixia). We recommend the software ONA developed by Chaloupková et al. (2016), which is currently the best method to promote panmixia in seed orchards to create optimal spatial layouts for planting the seed orchards.

5. Our future work in relation to seed orchards should be focused on the estimation of breeding values of single clones by testing their offspring families. These breeding values will help to plan genetic thinnings of the new seed orchards, if the spacing of plants is not too wide, and to design the genetic composition of an advanced generation of orchards in the forthcoming. Further, comprehensive field tests of progenies should be conducted to achieve the category "Tested" for superior seed orchards. Simultaneously, these tests should compare the offspring from the new orchards with already existing ones to draw inferences concerning their design from practical experience in addition to the stated theoretical considerations. Last, but not least, the expected new experiences will lead to an updated breeding strategy.

\section{Acknowledgments}

This review was produced in the framework of two national joint research projects "FitForClim" and "AdaptForClim" funded by the German Federal Ministry of Food and Agriculture and the Federal Ministry of the Environment, Nature Conservation and Nuclear Safety (Waldklimafonds, Grant numbers 22WB400704 and 22WB415204, administrated by the Agency for Renewable Resources and the Federal Office for Agriculture and Food). For helpful discussions we thank our colleagues Volker Schneck and Mirko Liesebach and all project partners. We do much appreciate the valuable review of Darius Danusevičius (Alexandras Stulginskis University, Lithuania) and Doris Krabel (Technical University Dresden, Germany), which further improved the manuscript. 


\section{References}

Adams WT, Burczyk J (2000) Magnitude and implications of gene flow in gene conservation reserves. In: Young A, D Boshier and T Boyle (eds). Forest conservation genetics: Principles and practice. Victoria, Australia: CSIRO Publishing, Collingwood, pp 215-244 https://doi.org/10.1079/9780851995045.0215

Ahtikoski A, Ojansuu R, Haapanen M, Hynynen J, Kärkkäinen K (2012) Financial performance of using genetically improved regeneration material of Scots pine (Pinus sylvestris L.) in Finland. New Forests 43(3):335-348. https://dx.doi.org/10.1007/s11056-011-9284-6

Andersson B, Elfving B, Ericsson T, Persson T, Gregorsson B (2003) Performance of Improved Pinus sylvestris in Northern Sweden. Scandinavian Journal of Forest Research 18(3):199-206. https://dx.doi.org/10.1080/02827581.2003.9728290

Bastien J-C, Sanchez L, Michaud D (2013) Douglas-Fir (Pseudotsuga menziesii (Mirb.) Franco). In: Pâques LE (ed) Forest Tree Breeding in Europe: Current State-of-the-Art and Perspectives. Dordrecht @ Springer Science+Business Media, pp 325-369. https://doi.org/10.1007/978-94-007-6146-9_7

Bell GD, Fletcher AM (1978) Computer organised orchard layouts (COOL) based on the permutated neighbourhood design concept. Silvae Genetica 27(6):223-225

Bishir J, Roberds JH (1997) Limit theorems and a general framework for risk analysis in clonal forestry. Mathematical Biosciences 142(1):1-11. https://doi.org/10.1016/s0025-5564(96)00184-8

Bishir J, Roberds JH (1999) On numbers of clones needed for managing risks in clonal forestry. Forest Genetics 6(3):149-155

BLE (2017) Forstliches Vermehrungsgut - Informationen für die Praxis. 9. Auflage. Bonn, Germany: BLE (Bundesanstalt für Landwirtschaft und Ernährung), 72 p, ISBN 978-3-8308-1291-3

BLE (2019) Übersicht über zugelassenes Ausgangsmaterial für forstliches Vermehrungsgut in der Bundesrepublik Deutschland (Stand: 01.07.2019) [online]. Available from https://www.ble.de/DE/Themen/Wald-Holz/Forstliches-Vermehrungsgut/forstliches-vermehrungsgut_node.html [cited August 8, 2020]

Burdon RD, Carson MJ, Shelbourne CJA (2008) Achievements in forest tree genetic improvement in Australia and New Zealand 10: Pinus radiata in New Zealand. Australian Forestry 71(4):263-279. https://dx.doi.org/10.1080/00049158.2008.10675045

Burrows P (1970) Coancestry control in forest tree breeding plans. Proceedings of the Second Meeting of the Working Group on Quantitative Genetics, Section 22 IUFRO, August 18-19, 1969, Raleigh, North Carolina: 27-36

Carson SD, Garcia O, Hayes JD (1999) Realized Gain and Prediction of Yield with Genetically Improved Pinus radiata in New Zealand. Forest Science 45(2):186-200. https://dx.doi.org/10.1093/forestscience/45.2.186

Cavers S, Degen B, Caron H, Lemes MR, Margis R, Salgueiro F, Lowe AJ (2005) Op timal sampling strategy for estimation of spatial genetic structure in tree populations. Heredity 95(281):289. https://doi.org/10.1038/sj.hdy.6800709

Chakravarty GN, Bagchi SK (1993) A computer program for permutated neighbourhood seed orchard design. Silvae Genetica 42:1-5

Chakravarty GN, Bagchi SK (1994) Short Note: Enhancement of the computer program of the permutated neighbourhood seed orchard design. Silvae Genetica 43(2):177-178

Chaloupková K, Stejskal J, El-Kassaby YA, Frampton J, Lstibůrek M (2019) Current advances in seed orchard layouts: Two Case Studies in Conifers. Forests 10(2):1-6. https://dx.doi.org/10.3390/f10020093

Chaloupková K, Stejskal J, El-Kassaby YA, Lstibůrek M (2016) Optimum neighborhood seed orchard design. Tree Genetics \& Genomes 12(6):105. https://dx.doi.org/10.1007/s11295-016-1067-y

Chambel MR, Climent J, Pichot C, Ducci F (2013) Mediterranean Pines (Pinus halepensis Mill. and brutia Ten.). In: Pâques LE (ed) Forest Tree Breeding in Europe: Current State-of-the-Art and Perspectives. Dordrecht $\odot$ Springer Science+Business Media, pp 229-265. https://doi.org/10.1007/978-94-007-6146-9 5

Costa e Silva J, Potts BM, Lopez GA (2014) Heterosis may result in selection favouring the products of long-distance pollen dispersal in Eucalyptus. PLoS ONE 9(4):e93811-e93811. https://dx.doi.org/10.1371/journal.pone.0093811
D'Amico I, Vilardi JC, Saidman BO, Ewens M, Bessega C (2019) Pollen contamination and mating patterns in a Prosopis alba clonal orchard: impact on seed orchards establishment. iForest - Biogeosciences and Forestry 12(3):330337. https://dx.doi.org/10.3832/ifor2936-012

Danusevičius D, Lindgren D (2002) Efficiency of selection based on phenotype, clone and progeny testing in long-term breeding. Silvae Genetica 5(1):1926

Danusevičius D, Lindgren D (2008) Strategies for optimal deployment of related clones into seed orchards. Silvae Genetica 57(1-6):119. https://doi.org/10.1515/sg-2008-0018

Danusevicius D, Kerpauskaite V, Kavaliauskas D, Fussi B, Konnert M, Baliuckas V (2016) The effect of tending and commercial thinning on the genetic diversity of Scots pine stands. European Journal of Forest Research 135(6):11591174. https://dx.doi.org/10.1007/s10342-016-1002-7

Darwin C (1877) The effects of cross and self fertilisation in the vegetable kingdom. London: D. Appleton, $486 \mathrm{p}$

Di-Giovanni F, Kevan PG (1991) Factors affecting pollen dynamics and its importance to pollen contamination: a review. Canadian Journal of Forest Research 21(8):1155-1170. https://dx.doi.org/10.1139/x91-163

Doerksen TK, Bousquet J, Beaulieu J (2014) Inbreeding depression in intra-provenance crosses driven by founder relatedness in white spruce. Tree Genetics \& Genomes 10(1):203-212. https://dx.doi.org/10.1007/s11295-013-0676-y

Durel CE, Bertin P, Kremer A (1996) Relationship between inbreeding depression and inbreeding coefficient in maritime pine (Pinus pinaster). Theoretical and Applied Genetics 92(3):347-356. https://dx.doi.org/10.1007/BF00223678

Edmands S (2007) Between a rock and a hard place: evaluating the relative risks of inbreeding and outbreeding for conservation and management. Molecular Ecology 16(3):463-475. https://doi.org/10.1111/j.1365-294x.2006.03148.x

Edmands S, Timmerman CC (2003) Modeling factors affecting the severity of outbreeding depression. Conservation Biology 17(3):883-892. https://dx.doi.org/10.1046/j.1523-1739.2003.02026.x

Edvardsen O, Steffenrem A, Johnskås O, Johnsen Ø, Myking T, Kvaalen H (2010) Strategi for Skogplanteforedling 2010-2040 (høringsutkast). Hamar, Norway, $27 \mathrm{p}$

El-Kassaby YA (2003) Clonal-row vs. random seed orchard designs: mating pattern and seed yield of western hemlock (Tsuga heterophylla (Raf.) Sarg.). Forest Genetics 10:121-127

El-Kassaby YA, Fayed M, Klápště J, Lstibůrek M (2014) Randomized, replicated, staggered clonal-row (R2SCR) seed orchard design. Tree Genetics \& Genomes 10(3):555-563. https://dx.doi.org/10.1007/s11295-014-0703-7

El-Kassaby YA, Stoehr MU, Reid D, Walsh CG, Lee TE (2007) Clonal-row versus random seed orchard designs: interior spruce mating system evaluation. Canadian Journal of Forest Research 37(3):690-696. https://dx.doi.org/10.1139/X06-248

Eriksson G (1998) Evolutionary forces influencing variation among populations of Pinus sylvestris. Silva Fennica 32:173-184 https://doi.org/10.14214/sf.694

Eriksson G, llstedt B (1986) Stem volume of intra-and interprovenance families of Picea abies (L.) Karst. Scandinavian Journal of Forest Research 1(1-4):141152. https://doi.org/10.1080/02827588609382407

Eusemann P, Liesebach H (2021) Small-scale genetic structure and mating patterns in an extensive sessile oak forest (Quercus petraea (MATT.) LIEBL.). Ecology and Evolution, in press https://dx.doi.org/10.002/ece3.7613

Fernandes L, Rocheta M, Cordeiro J, Pereira S, Gerber S, Oliveira MM, Ribeiro MM (2008) Genetic variation, mating patterns and gene flow in a Pinus pinaster Aiton clonal seed orchard. Annals of Forest Science 65(7):706-706. https:// dx.doi.org/10.1051/forest:2008049

Ford GA, McKeand SE, Jett JB, Isik F (2014) Effects of Inbreeding on Growth and Quality Traits in Loblolly Pine. Forest Science 61(3):579-585. https://dx.doi.org/10.5849/forsci.13-185

Forrest CN, Ottewell KM, Whelan RJ, Ayre DJ (2011) Tests for inbreeding and outbreeding depression and estimation of population differentiation in the bird-pollinated shrub Grevillea mucronulata. Annals of Botany 108(1):185195. https://dx.doi.org/10.1093/aob/mcr100 
Freeman GH (1967) The use of cyclic balanced incomplete block designs for directional seed orchards. Biometrics:761-778. https://doi.org/10.2307/2528427

Fries A, Lindgren D, Andersson B (2008) The Swedish Scots pine seed orchard Västerhus: a study of linear deployment. Proceedings of the Seed Orchards Conference, 26-28 September, 2007, Umeá, Sweden: 70-78

Funda T, Chen CC, Liewlaksaneeyanawin C, Kenawy AMA, El-Kassaby YA (2008) Pedigree and mating system analyses in a western larch (Larix occidentalis Nutt.) experimental population. Annals of Forest Science 65(7):705. https:// dx.doi.org/10.1051/forest:2008055

Funda T, El-Kassaby YA (2012) Seed orchard genetics. CAB Reviews 7(013):1-23. https://doi.org/10.1079/pavsnnr20127013

Giertych M (1975) Seed orchard designs. In: Faulkner R (ed) Seed orchards. A joint production by specialist members of the International Union of Forest Research Organization's Working Party on seed orchards (S2.03.3). London, UK: Forestry Commission, pp 25-37, ISBN 0-11-710146-X

gGA [gemeinsamer Gutachterausschuss] (2019) Forstvermehrungsgutrecht: Empfehlungen des gemeinsamen Gutachterausschusses (gGA) der Länder für dessen Umsetzung. $86 \mathrm{p}$. https://www.ble.de/DE/Themen/Wald-Holz/Forstliches-Vermehrungsgut/

Gonzáles-Martínez SC, Gerber S, Cervera M-T, Martínez-Zapater J, Gil L, Alía R (2002) Seed gene flow and fine-scale structure in a Mediterranean pine ( $P$ inus pinaster Ait.) using nuclear microsatellite markers. TAG Theoretical and Applied Genetics V104(8):1290-1297. https://dx.doi.org/10.1007/s00122-002-0894-4

Goto S, lijima H, Ogawa H, Ohya K (2011) Outbreeding depression caused by intraspecific hybridization between local and nonlocal genotypes in Abies sachalinensis. Restoration Ecology 19(2):243-250. https://dx.doi.org/10.1111/j.1526-100X.2009.00568.x

Grotehusmann H (1998) Geprüftes Vermehrungsgut aus Kiefern- und Erlen-Samenplantagen. AFZ-Der Wald 53:240-242

Grotehusmann H (2014a) Prüfung von 25 jährigen Absaaten aus Kiefern-Samenplantagen. Landbauforschung - Applied Agricultural and Forestry Research 64(2):107-118. https://dx.doi.org/10.3220/LBF 2014 107-118

Grotehusmann H (2014b) Prüfung von Fichten-Samenplantagen. AFZ-Der Wald 69(5):6-9

Haapanen M, Jansson G, Nielsen UB, Steffenrem A, Stener L-G (2015) The status of tree breeding and its potential for improving biomass production: a review of breeding activities and genetic gains in Scandinavia and Finland. Uppsala, Sweden: SkogForsk, $56 \mathrm{p}$

Hannrup B, Cahalan C, Chantre G, Grabner M, Karlsson B, Bayon IL, Jones GL, Müller U, Pereira H, Rodrigues JC, Rosner S, Rozenberg P, Wilhelmsson L, Wimmer R (2004) Genetic parameters of growth and wood quality traits in Picea abies. Scandinavian Journal of Forest Research 19(1):14-29. https://dx.doi.org/10.1080/02827580310019536

Hansen J, Roulund H (1997) Genetic parameters for spiral grain, stem Form, Pilodyn and growth in 13 years old clones of Sitka spruce (Picea sitchensis (BONG.) CARR.). Silvae Genetica 46(2):107-112

Harfouche A, Bahrman N, Baradat P, Guyon JP, Petit RJ, Kremer A (2000) Provenance hybridization in a diallel mating scheme of maritime pine (Pinus pinaster). II. Heterosis. Canadian Journal of Forest Research 30(1):10-16. https://dx.doi.org/10.1139/x99-179

Harfouche A, Kremer A (2000) Provenance hybridization in a diallel mating scheme of maritime pine (Pinus pinaster). I. Means and variance components. Canadian Journal of Forest Research 30(1):1-9. https://dx.doi.org/10.1139/x99-178

Hattemer HH, Ziehe M (2018) Erhaltung forstgenetischer Ressourcen - Grundlagen und Beispiele. Göttingen University Press, ISBN 978-3-86395-362-1. https://doi.org/10.17875/gup2018-1094

Hedrick PW, Hellsten U, Grattapaglia D (2016) Examining the cause of high inbreeding depression: analysis of whole-genome sequence data in 28 selfed progeny of Eucalyptus grandis. New Phytologist 209(2):600-611. https://dx.doi.org/10.1111/nph.13639

Hofgaard A (1993) Seed rain quantity and quality, 1984-1992, in a high altitude old-growth spruce forest, northern Sweden. New Phytologist 125(3):635640. https://dx.doi.org/10.1111/j.1469-8137.1993.tb03913.x
Hufford KM, Hamrick JL (2003) Viability selection at three early life stages of the tropical tree, Platypodium elegans (Fabaceae, Papilonideae). Evolution 57(3):518-526. https://doi.org/10.1111/j.0014-3820.2003.tb01543.x

Hüller W, Svolba J, Kleinschmit J (1995) Entwicklung von Kiefernplantagenabsaaten in Niedersachsen. Forst und Holz 50:142-144

Ingvarsson PK, Dahlberg H (2019) The effects of clonal forestry on genetic diversity in wild and domesticated stands of forest trees. Scandinavian Journal of Forest Research 34(5):370-379. https://dx.doi.org/10.1080/02827581.2018.1469665

Ivetić V, Devetaković J, Nonić M, Stanković D, Šijačić-Nikolić M (2016) Genetic diversity and forest reproductive material - from seed source selection to planting. iForest - Biogeosciences and Forestry 9(5):801-812. https://dx.doi.org/10.3832ifor1577-009

Jansson G, Hansen JK, Haapanen M, Kvaalen H, Steffenrem A (2017) The genetic and economic gains from forest tree breeding programmes in Scandinavia and Finland. Scandinavian Journal of Forest Research 32(4):273-286. https://dx.doi.org/10.1080/02827581.2016.1242770

Johnson R, Lipow S (2002) Compatibility of breeding for increased wood production and longterm sustainability: the genetic variation of seed orchard seed and associated risks. Proceedings of the Wood compatibility initiative workshop Number 18, 169-179

Kess T, El-Kassaby YA (2015) Estimates of pollen contamination and selfing in a coastal Douglas-fir seed orchard. Scandinavian Journal of Forest Research 30(4):266-275. https://dx.doi.org/10.1080/02827581.2015.1012112

Kleinschmit J (1988) Konsequenzen aus den Lärchen-Herkunftsversuchen für die Lärchen-Züchtung. Forst und Holz 43(11):259-262

Kohlstock N, Schneck H (1992) Scots pine breeding (Pinus sylvestris L.) at Waldsieversdorf and its impact on pine management in the Northeastern German Lowland. Silvae Genetica 41(3):174-180

Korecký J, El-Kassaby YA (2016) Pollination dynamics variation in a Douglas-fir seed orchard as revealed by microsatellite analysis. Silva Fennica 50:1-12

La Bastide JGA (1967) A computer program for the layouts of seed orchards. Euphytica 16(3):321-323. https://dx.doi.org/10.1007/BF00028937

Lai BSK, Funda T, Liewlaksaneeyanawin C, Klápště J, Van Niejenhuis A, Cook C, Stoehr MU, Woods JH, El-Kassaby YA (2010) Pollination dynamics in a Douglas-fir seed orchard as revealed by pedigree reconstruction. Annals of Forest Science 67(8):808. https://doi.org/10.1051/forest/2010044

Langner W, Schneck V (1998) Ein Beitrag zur Züchtung von Hybridlärchen (Larix $x$ eurolepis HENRY). Frankfurt am Main: Sauerländer's Verlag, $159 \mathrm{p}$

Li B, McKeand S, Weir R (1999) Tree improvement and sustainable forestry-impact of two cycles of loblolly pine breeding in the USA. Forest Genetics 6(4):229-234

Libby WJ (1982) What is a safe number of clones per plantation? Proceedings of the Genetics of host-parasite interactions in forestry, 14-21 September 1980, Wageningen, The Netherlands: 342-360

Liepe KJ, Liesebach M (2017) Verwendungszonen für Vermehrungsgut von Douglasie auf Basis von Klimadaten und Herkunftsversuchen. Proceedings of the Hochwertiges Forstvermehrungsgut im Klimawandel - Symposium des Verbundprojektes FitForClim vom 14. bis 15. Juni 2016 in Chorin, Chorin, Germany: 39-54

Liesebach H, Eusemann P, Liesebach M (2015) Verwandtschaftsbeziehungen innerhalb von Prüfgliedern in Herkunftsversuchen - Beispiel Buche (Fagus sylvatica L.). Forstarchiv 86(6):174-182. https://dx.doi.org/10.4432/0300-4112-86-174

Liesebach M, Degen B, Grotehusmann H, Janßen A, Konnert M, Rau H-M, Schirmer R, Schneck D, Schneck V, Steiner W, Wolf H (2013) Strategie zur mittelund langfristigen Versorgung mit hochwertigem forstlichem Vermehrungsgut durch Züchtung in Deutschland. ISSN 2196-2324. Braunschweig, Germany: Thünen Institute, 69 p, ISBN 978-3-86576-107-1

Liesebach M, Liesebach H, Schneck V, Bäucker C, Eusemann P, Heimpold C, Liepe KJ, Pakull B, Rieckmann C, Schröder J, Wojacki J (2020) Bereitstellung von leistungsfähigem und hochwertigem Forstvermehrungsgut für den klimaund standortgerechten Wald der Zukunft (FitForClim) -Teilprojekt 4. Großhansdorf, Germany, $66 \mathrm{p}$

Lindgren D, Danusevicius D, Rosvall O (2009) Unequal deployment of clones to seed orchards by considering genetic gain, relatedness and gene diversity. Forestry: An International Journal of Forest Research 82(1):17-28. https://dx.doi.org/10.1093/forestry/cpn033 
Lindgren D, El-Kassaby YA (1989) Genetic consequences of combining selective cone harvesting and genetic thinning in clonal seed orchards. Silvae Genetica 38(2):65-70

Lindgren D, Matheson AC (1986) An algorithm for increasing the genetic quality of seed from seed orchards by using the better clones in higher proportions. Silvae Genetica 35(5-6):173-177

Lindgren D, Mullin TJ (1997) Balancing gain and relatedness in selection. Silvae Genetica 46(2):124-128

Lindgren D, Prescher F (2005) Optimal clone number for seed orchards with tested clones. Silvae Genetica 54(1-6):80. https://dx.doi.org/10.1515/sg-2005-0013

Lopez GA, Potts BM, Vaillancourt RE, Apiolaza LA (2003) Maternal and carryover effects on early growth of Eucalyptus globulus. Canadian Journal of Forest Research 33(11):2108-2115. https://dx.doi.org/10.1139/x03-132

Lstibůrek M, El-Kassaby YA (2008) Advanced-generation seed orchard designs. Proceedings of the Seed Orchard Conference, 26-28 September 2007, Umeå, Sweden: 155-160

Lstibůrek M, El-Kassaby YA (2010) Minimum-inbreeding seed orchard design. Forest Science 56(6):603-608 https://dx.doi.org/10.1093/forestscience/56.6.603

Lstibůrek M, Stejskal J, Misevicius A, Korecký J, El-Kassaby YA (2015) Expansion of the minimum-inbreeding seed orchard design to operational scale. Tree Genetics \& Genomes 11(1):1-8. https://dx.doi.org/10.1007/s11295-015-0842-5

MacLachlan IR, Wang T, Hamann A, Smets P, Aitken SN (2017) Selective breeding of lodgepole pine increases growth and maintains climatic adaptation. Forest Ecology and Management 391:404-416. https://dx.doi.org/https://doi.org/10.1016/j.foreco.2017.02.008

McKeand E, Beineke $F(1980)$ Sublining for half-sib breeding populations of forest trees. Silvae Genetica 29(1):14-17

Meißner M, Volmer K, Hardtke A, Stiehm C, Steiner W (2020) Bereitstellung von leistungsfähigem und hochwertigem Forstvermehrungsgut für den klimaund standortgerechten Wald der Zukunft (FitForClim) - Teilprojekt 1 -. Hann. Münden, Germany, $66 \mathrm{p}$

Merzeau D, Alazard P, Canteloup D, Crémière L, Daubet A, Lesgourgues Y, Pastuszka P, Raffin A (2005) Genetic breeding of the maritime pine in Aquitaine: an exemplary success story. Pierroton, France: Groupe Pin Maritime du Futur, $31 \mathrm{p}$

Montalvo AM, Ellstrand NC (2001) Nonlocal transplantation and outbreeding depression in the subshrub Lotus scoparius (Fabaceae). American Journal of Botany 88(2):258-269. https://dx.doi.org/10.2307/2657017

Morgante M, Vendramin GG, Rossi P, Olivieri AM (1993) Selection against inbreds in early life-cycle phases in Pinus leucodermis Ant. Heredity 70(6):622-627. https://dx.doi.org/10.1038/hdy.1993.89

Mullin TJ (2014) OPSEL 1.0: a computer program for optimal selection in forest tree breeding. Arbetsrapport från Skogforsk TechnicalReport Nr 841-2014, Report No: ISSN 1404-305X, $19 \mathrm{p}$

Mullin TJ (2017) OPSEL 2.0: a computer program for optimal selection in tree breeding. Report No: ISSN 1404-305X, $24 \mathrm{p}$

Mullin TJ, Persson T, Abrahamsson S, Andersson Gull B (2019) Effects of inbreeding depression on seed production in Scots pine (Pinus sylvestris). Canadian Journal of Forest Research 49(7):854-860. https://dx.doi.org/10.1139/cjfr-2019-0049

Namkoong G (1966) Inbreeding effects on estimation of genetic additive variance. Forest Science 12(1):8-13. https://dx.doi.org/10.1093/forestscience/12.1.8

Namkoong G, Bishir J (1987) The frequency of lethal alleles in forest tree populations. Evolution 41(5):1123-1126. https://doi.org/10.1111/j.1558-5646.1987.tb05882.x

Oakley CG, Ågren J, Schemske DW (2015) Heterosis and outbreeding depression in crosses between natural populations of Arabidopsis thaliana. Heredity 115(1):73-82. https://dx.doi.org/10.1038/hdy.2015.18

Okada M, Kitamura K, Lian C, Goto S (2015) The effects of multilocus heterozygosity on the longevity of seedlings established on fallen logs in Picea jezoensis and Abies sachalinensis. Open Journal of Forestry Vol.05No.04:9. https://dx.doi.org/10.4236/ojf.2015.54036

Olsson T, Lindgren D, Li B (2001) Balancing genetic gain and relatedness in seed orchards. Silvae Genetica 50(5-6):222-226
Pakull B, Eusemann P, Wojacki J, Ahnert D, Liesebach H: Genetic diversity of seeds from four German Douglas fir (Pseudotsuga menziesii) seed orchards. unpublished

Pâques LE (2013a) Forest tree breeding in Europe - Current State-of-the-Art and Perspectives. Springer, 527 p. https://doi.org/10.1007/978-94-007-6146-9

Pâques LE (2009) Growth rhythm parameters as components of hybrid vigour in young seedlings of hybrid larch (Larix decidua $\times$ L. kaempferi). 58(1-6):42. https://dx.doi.org/https://doi.org/10.1515/sg-2009-0006

Pâques LE (2013b) Introduction. In: Pâques EL (ed) Forest Tree Breeding in Europe: Current State-of-the-Art and Perspectives. Dordrecht $\odot$ Springer Science+Business Media, pp 1-9. https://doi.org/10.1007/978-94-007-6146-9 1

Pupin S, Sebbenn AM, Cambuim J, da Silva AM, Zaruma DUG, Silva PHM, Rosse LN, Souza ICG, Marino CL, Moraes MLT (2019) Effects of pollen contamination and non-random mating on inbreeding and outbreeding depression in a seedling seed orchard of Eucalyptus urophylla. Forest Ecology and Management 437:272-281. https://dx.doi.org/https://doi.org/10.1016/j.foreco.2019.01.050

Pyhäjärvi T, Kujala ST, Savolainen O (2020) 275 years of forestry meets genomics in Pinus sylvestris. Evolutionary Applications 13(1):11-30. https://dx.doi.org/10.1111/eva.12809

Rau HM (1998) Vermehrungsgut von Samenplantagen im Vergleich zu handelsüblichem Material. AFZ-Der Wald 53(5):236-239

Rau HM, Schulzke R (2001) Beitrag forstlicher Samenplantagen bei der Bereitstellung herkunftsgesicherten Vermehrungsgutes. Proceedings of the FORUM Genetik-Wald-Forstwirtschaft: Herkunftssicherung und Zertifizierung von forstlichem Vermehrungsgut, June 11-13, 2001, Freiburg, Germany: 6671

Rood SB, Goater LA, McCaffrey D, Montgomery JS, Hopkinson C, Pearce DW (2017) Growth of riparian cottonwoods: heterosis in some intersectional Populus hybrids and clonal expansion of females. Trees 31(3):1069-1081. https://dx.doi.org/10.1007/s00468-017-1531-9

Rosvall O, Jansson G, Andersson B, Ericsson T, Karlsson B, Sonesson J, Stener L-G (2001) Genetiska vinster i nuvarande och framtida fröplantager och klonblandningar. Uppsala (Sweden): SkogForsk, Technical Report, Report Number: Skogforsk-RED-1-2001, Report No: ISSN 1103-4580; TRN: SE0107372, 41 $\mathrm{p}$

Saksa T (2004) Regeneration process from seed crop to saplings-A case study in uneven-aged norway spruce-dominated stands in southern Finland. Silva Fennica 38(4):371-381. https://doi.org/10.14214/sf.405

Sarvas R (1962) Investigations on the flowering and seed crop of Pinus silvestris. Helsinki, Finland, 198 p, ISBN 0026-1610

Schneck V (2001) Bestände und Samenplantagen von Gemeiner Kiefer. AFZ-Der Wald 56(5):232-233

Shull GH (1952) Beginnings of the heterosis concept. In: Gowen JW (ed) Heterosis. lowa State College Press pp 14-48

Silva P, Brune A, Pupin S, Moraes M, Sebbenn A, de Paula R (2018) Maintenance of genetic diversity in Eucalyptus urophylla S. T. Blake populations with restriction of the number of trees per family. Silvae Genetica 67(1):34-40. https://dx.doi.org/10.2478/sg-2018-0005

Slavov GT, Howe GT, Adams WT (2005) Pollen contamination and mating patterns in a Douglas-fir seed orchard as measured by simple sequence repeat markers. Canadian Journal of Forest Research 35(7):1592-1603. https://doi.org/10.1139/x05-082

Song J, Ratcliffe B, Kess T, Lai BS, Korecký J, El-Kassaby YA (2018) Temporal quantification of mating system parameters in a coastal Douglas-fir seed orchard under manipulated pollination environment. Scientific Reports 8(1):11593. https://dx.doi.org/10.1038/s41598-018-30041-4

Sønstebø JH, Tollefsrud MM, Myking T, Steffenrem A, Nilsen AE, Edvardsen ØM, Johnskås OR, El-Kassaby YA (2018) Genetic diversity of Norway spruce (Picea abies (L.) Karst.) seed orchard crops: Effects of number of parents, seed year, and pollen contamination. Forest Ecology and Management 411:132-141. https://dx.doi.org/https://doi.org/10.1016/j.foreco.2018.01.009

Stacy EA (2001) Cross-fertility in two tropical tree species: evidence of inbreeding depression within populations and genetic divergence among populations. American Journal of Botany 88(6):1041-1051. https://dx.doi.org/10.2307/2657086 
Stephan BR, Liesebach M (1996) Results of the IUFRO 1982 Scots pine (Pinus sylvestris L.) provenance experiment in southwestern Germany. Silvae Genetica 45(5-6):342-349

Stoehr MU, Ott P, Woods JH (2015) Inbreeding in mid-rotation coastal Douglas-fir: implications for breeding. Annals of Forest Science 72(2):195-204. https://dx.doi.org/10.1007/s13595-014-0414-0

Stoehr MU, Webber J, Woods JH (2004) Protocol for rating seed orchard seedlots in British Columbia: quantifying genetic gain and diversity. Forestry: An International Journal of Forest Research 77(4):297-303. https://dx.doi.org/10.1093/forestry/77.4.297

Talbert J (1979) An advanced-generation breeding plan for the NC State University-Industry pine tree improvement cooperative. Silvae Genetica 28(2/3):72-75

Templeton AR (1986) Coadaptation and outbreeding depression. In: Soule ME (ed) Conservation Biology-The Science of Scarcity and Diversity. Sinauer Associates, pp 105-116, ISBN ISSN: 0878937943

Torimaru T, Wang X-R, Fries A, Andersson B, Lindgren D (2009) Evaluation of pollen contamination in an advanced Scots pine seed orchard. Silvae Genetica 58(1-6):262-269.https://doi.org/10.1515/sg-2009-0033

Torimaru T, Wennström U, Andersson B, Almqvist C, Wang X-R (2013) Reduction of pollen contamination in Scots pine seed orchard crop by tent isolation. Scandinavian Journal of Forest Research 28(8):715-723. https://dx.doi.org/10.1080/02827581.2013.838298

Van Buijtenen JP (1975) The planning and strategy of seed orchard programmes, including economics. In: Faulkner R (ed) Seed orchards. London, UK: Forestry Commission, pp 9-24

Vanclay JK (1991) Seed orchard designs by computer. Silvae Genetica 40:89-91 Vergara R, White TL, Huber DA, Shiver BD, Rockwood DL (2004) Estimated realized gains for first-generation slash pine (Pinus elliottii var. elliottii) tree improvement in the southeastern United States. Canadian Journal of Forest Research 34(12):2587-2600. https://dx.doi.org/10.1139/x04-136

Wang Q, Qi J, Cui X, Li W (2018) Application of improved genetic algorithm in clonal deployment for seed orchard (in Chinese). Sci. Silv. Sin. 54(4):30-37

White TL, Hodge G, Powell G (1993) An advanced-generation tree improvement plan for slash pine in the southeastern United States. Silvae Genetica 42(6):359-371

Williams CG, Savolainen O (1996) Inbreeding depression in conifers: Implications for breeding strategy. Forest Science 42(1):102-117. https://dx.doi.org/10.1093/forestscience/42.1.102

Wojacki J, Eusemann P, Ahnert D, Pakull B, Liesebach H (2019) Genetic diversity in seeds produced in artificial Douglas-fir (Pseudotsuga menziesii) stands of different size. Forest Ecology and Management 438:18-24. https://dx.doi.org/10.1016/j.foreco.2019.02.012

Woods JH, Heaman JC (1989) Effect of different inbreeding levels on filled seed production in Douglas-fir. Canadian Journal of Forest Research 19(1):54-59. https://dx.doi.org/10.1139/x89-007

Woods JH, Wang T, Aitken SN (2002) Effects of inbreeding on coastal Douglas-fir: nursery performance. Silvae Genetica 51(4):163-170

Wray N, Goddard M (1994) Increasing long-term response to selection. Genetics Selection Evolution 26(5):431. https://doi.org/10.1186/1297-9686-26-5-431

Wu H, Ivkovic M, Gapare W, Matheson A, Baltunis B, Powell M, McRae T (2008) Breeding for wood quality and profit in Pinus radiata: a review of genetic parameter estimates and implications for breeding and deployment. New Zealand Journal of Forestry Science 38(1):56-87

Yamashita M, Mullin TJ, Safarina S (2018) An efficient second-order cone programming approach for optimal selection in tree breeding. Optimization Letters 12(7):1683-1697. https://dx.doi.org/10.1007/s11590-018-1229-y

Yang B, Sun H, Qi J, Niu S, El-Kassaby YA, Li W (2020) Improved genetic distance-based spatial deployment can effectively minimize inbreeding in seed orchard. Forest Ecosystems 7(1):10. https://dx.doi.org/10.1186/s40663-020-0220-0

Yao J, Li H, Ye J, Shi L (2016) Relationship between parental genetic distance and offspring's heterosis for early growth traits in Liriodendron: implication for parent pair selection in cross breeding. New Forests 47(1):163-177. https://dx.doi.org/10.1007/s11056-015-9508-2

Zanewich KP, Pearce DW, Rood SB (2018) Heterosis in poplar involves phenotypic stability: cottonwood hybrids outperform their parental species at sub- optimal temperatures. Tree Physiology 38(6):789-800.

https://dx.doi.org/10.1093/treephys/tpy019

Zobel BJ, Weir RJ, Jett JB (1972) Breeding Methods to Produce Progeny for Advanced-generation Selection and to Evaluate Parent Trees. Canadian Journal of Forest Research 2(3):339-345. https://dx.doi.org/10.1139/x72-052 